\title{
Assessment Considerations in Pediatric Patients
}

\author{
Deonne Dersch-Mills
}

\section{Chapter Objectives}

1. Recognize challenges related to patient assessment that are unique to pediatrics and neonatology.

2. Describe the required components of a complete pharmacy assessment that are unique to pediatrics and neonatology.

3. Gain a basic understanding of the differences in pediatric assessment as it relates to vital signs and common laboratory parameters.

\section{Background}

Pediatric pharmacy technically includes the care of any patient under the age of 18 years, although practically patients over the age of 15 can usually be cared for following similar dosing/monitoring as in adults. In Canada in 2017, children under 12 years comprised $\sim 15 \%$ of the Canadian population (Statistics Canada, Population by sex and age group 2017), and accounted for $6.4 \%$ of hospital discharges ( $\sim 3 \%$ not including births in hospital) [1]. Approximately $50 \%$ of Canadian children receive one or more medications each year; this is up to $79 \%$ in infants $<1$ year old $[2,3]$. While

\footnotetext{
D. Dersch-Mills $(\bowtie)$

Pharmacy Services, Alberta Health Services,

Calgary, AB, Canada

e-mail: deonne.dersch-mills@ahs.ca
}

medication use is not uncommon, polypharmacy is much less common than in adult patients. Around $20 \%$ of US children received at least one medication in the previous week, but less than $6 \%$ had used two or more medications in the previous week $[4,5]$. The most common medications filled for children in community pharmacies in 2012 included antibiotics (amoxicillin, azithromycin, and cefprozil most commonly), asthma medications (salbutamol, fluticasone, montelukast), and medications for attention deficit hyperactivity disorder (ADHD) (methylphenidate primarily) [2].

Before moving forward, it is important for pharmacists to understand age-related terminology for children. Gestational age (GA) is the duration of time a newborn has been in utero (full term is considered $\sim 40$ weeks) while post-natal age (PNA), also known as chronological age (CA), is the duration of time since birth (e.g., 2 weeks old). Corrected gestational age (CGA) or post-menstrual age (PMA) are terms used most commonly in infants born prematurely, and refer to their gestational age plus post-natal age. For instance, a baby born at 30 weeks GA, with a PNA/CA of 10 days would have a CGA/PMA of 31 weeks and 3 days (commonly abbreviated as $31+3$ weeks). A neonate (or newborn) is an infant $<28$ days PNA/CA, or for premature infants, less than 44 weeks CGA/PMA. The term "infant" typically refers to a range of PNA/CA from 28 days to 1 year. The term "toddler" typically refers to age 1-3 years, and "school-age" 
refers to age from 4 to 9 years. "Adolescent" typically refers to age 10-19 years, though the true onset of adolescence is determined by the onset of puberty. These distinctions are important due to developmental changes that occur in pharmacokinetics (see more below).

There is a distinct lack of research on medication use in children, which adds its own challenges to the practice of pharmacy in children. Up to $90 \%$ of medication use in hospitalized children and $30 \%$ of medication use in ambulatory children are considered "off-label," that is, not included in the product labeling/monograph and thus not supported by the manufacturer [2]. Only $25 \%$ of medications on the market are approved for children, and this number is even less for infants [6]. This results in a lack of detailed pharmacokinetic, dosing, adverse effect, and efficacy data for appropriate medication management in children. As well, due to the lack of studied indications in children, there is little impetus for manufacturers to make formulations appropriate for children and so formulation issues related to availability, palatability, excipients, or measurability are commonplace.

Due to the abovementioned factors, children are at higher risk of medication errors and have a higher risk of harm from medication errors, so the pharmacist plays an important role in caring for infants and children who use medications [7]. Approximately $8 \%$ of pediatric Emergency Department visits are medication-related, of which $2 / 3$ are deemed preventable (examples include adverse drug reactions, sub-therapeutic doses, or non-adherence due to a variety of factors) [8]. There are an estimated 0.85 adverse drug reactions per 100 inpatient admissions in pediatrics, of which $21 \%$ would be considered preventable [9]. Statistics like this highlight the importance of a complete pharmacist assessment for children using medications.

In many ways, assessment of a pediatric patient is not different than assessment of an adult patient. Pharmacists should gather information on medical history, medication history, medical conditions, and any other relevant information, and then ensure that all medications are indicated, dosed appropriately, effective, safe, and adhered to. However, each of these steps contains nuances for infants and children. There may be additional steps within each component of the assessment, and there is a significantly smaller evidence base to support decisions and judgment calls made within each step of the assessment.

\section{Pharmacokinetic Differences}

One of the major nuances between pediatric and adult assessments is the need to consider pharmacokinetic ontogeny, or pharmacokinetic differences based on the age of the child. While it is not surprising that there are pharmacokinetic differences between children and adults, there are also important differences between premature newborns, term newborns, infants, toddlers, schoolage children, and adolescents. Table 28.1 provides a summary of major pharmacokinetic considerations in infants and children. This variability in pharmacokinetics makes dosing medications in children especially challenging as there is no "standard" dose of a medication. Medication doses may vary based on CGA, PNA, as well as body weight or surface area. Most notable is the need to use neonatal (not pediatric) dosing in newborns as the first few months of life are characterized by rapidly changing organ function (renal and hepatic most importantly) as well as changes in drugs' volume of distribution.

Typically, newborns are characterized by reduced renal and hepatic clearance at birth (especially with premature birth), which develops rapidly in the first month of life and reaches adult values at 6 months to 1 year of age. Childhood is typically characterized by excellent renal and hepatic clearance, even exceeding that of adults in some cases. Normal clearance values approach that of adults around adolescence. This is an oversimplification, given that different aspects of renal and hepatic clearance develop at different rates. Full reviews of pharmacokinetic differences in children can be found in Kearns et al. [10] and Bartelink et al. [11]. By selecting age-appropriate doses, the pharmacokinetic differences that occur throughout childhood are taken into account. All pharmacists should ensure that medication doses in children are age and/or weight appropriate by consulting neonatal and/or pediatric dosing references with each and every prescription. 
Table 28.1 Summary of pharmacokinetic considerations throughout childhood [10, 11]

\begin{tabular}{|c|c|c|c|c|}
\hline & Neonates & Infants & Children & Adolescents \\
\hline $\begin{array}{l}\text { Absorption - } \\
\text { enteral }\end{array}$ & \multicolumn{2}{|c|}{$\begin{array}{l}\text { Changes in the degree of absorption of some medications } \\
\text { due to elevated gastric } \mathrm{pH} \text { and reduced pool of bile salts } \\
\text { Changes in rate of absorption due to prolonged gastric } \\
\text { emptying } \\
\text { Consider frequent feeds (for medications requiring an } \\
\text { empty stomach, this is challenging with q3-4 h feeds) and } \\
\text { frequent spit-ups/regurgitation (include counseling on } \\
\text { what to do if baby spits up after taking medication) }\end{array}$} & $\begin{array}{l}\text { Biggest factor relates } \\
\text { to ability to take } \\
\text { medication (related to } \\
\text { taste and } \\
\text { formulations) }\end{array}$ & $\begin{array}{l}\text { Non-compliance } \\
\text { becomes an } \\
\text { increasingly } \\
\text { important factor }\end{array}$ \\
\hline $\begin{array}{l}\text { Absorption - } \\
\text { other routes }\end{array}$ & \multicolumn{2}{|c|}{$\begin{array}{l}\text { Rectal - consider frequent stooling patterns. } \\
\text { First-pass metabolism may be bypassed depending on the } \\
\text { depth of insertion (lower insertion will bypass first pass } \\
\text { metabolism via lower and middle rectal veins, higher } \\
\text { insertion still goes through first pass via upper rectal } \\
\text { vein) } \\
\text { Percutaneous - much higher in neonates (especially } \\
\text { premature) due to immature keratinization (first } 2 \text { weeks } \\
\text { of life), high body surface area: volume ratio and high } \\
\text { blood flow to skin. Use caution with topical steroids } \\
\text { (lowest potency possible) }\end{array}$} & Similar to adults & Similar to adults \\
\hline Distribution & \multicolumn{2}{|c|}{$\begin{array}{l}\text { Increased volume of distribution for water-soluble } \\
\text { medications. Approaches adult values around } \\
6-9 \text { months. } \\
\text { Increased CNS permeability in newborn period and early } \\
\text { infancy. } \\
\text { Reduced protein binding of medications in neonatal } \\
\text { period and early infancy (due to altered binding proteins } \\
\text { as well as displacing substances such as bilirubin) }\end{array}$} & Similar to adults & Similar to adults \\
\hline Metabolism & $\begin{array}{l}\text { Reduced (in general) } \\
\text { Phase I: CYP3A7 mature at } \\
\text { birth, CYP2E1, CYP2D6 } \\
\text { mature in around } 2 \text { weeks } \\
\text { Phase II: sulfation and } \\
\text { methylation relatively mature at } \\
\text { birth }\end{array}$ & $\begin{array}{l}\text { Variable } \\
\text { Phase I: CYP3A4, } \\
2 \mathrm{C} 9,2 \mathrm{C} 19,1 \mathrm{~A} 2 \\
\text { mature } 6 \text { months to } \\
1 \text { year } \\
\text { Phase II: } \\
\text { glucuronidation mature } \\
2 \text { months to } 3 \text { years; } \\
\text { acetylation mature in } \\
1-4 \text { years } \\
\text { (note other pathways } \\
\text { may take over for } \\
\text { immature systems, e.g., } \\
\text { sulfation of } \\
\text { acetaminophen) }\end{array}$ & $\begin{array}{l}\text { Increased (in } \\
\text { general); typically } \\
\text { exceeding adult } \\
\text { values (i.e., frequently } \\
\text { require higher } \mathrm{mg} / \mathrm{kg} \\
\text { doses) }\end{array}$ & Similar to adults \\
\hline Elimination & $\begin{array}{l}\text { Reduced at birth; both GFR and } \\
\text { tubular secretion rapidly double } \\
\text { in first } 1-2 \text { weeks of life }\end{array}$ & $\begin{array}{l}\text { Developing - reaches } \\
\text { adult values } 6 \text { months } \\
\text { to } 1 \text { year }\end{array}$ & $\begin{array}{l}\text { Increased (in general) } \\
\text { reabsorption matures } \\
\sim 2-3 \text { years }\end{array}$ & Similar to adults \\
\hline
\end{tabular}

CYP Cytochrome P450

\section{Steps in Assessment}

\section{Information Gathering}

In pediatric practice, the gathering of patient history is often not done with the patient themselves. Until children are mature enough to provide this information themselves (note that this age varies depending on the child), parents and other caregivers are relied upon to provide an accurate history of the patient's illness(s) and medication(s). This provides an extra challenge to history gathering as the most appropriate person may not be available to provide this history, depending on the circumstances of the child's illness. Changing custody or living arrangements may impact a caregiver's ability to provide a history, 
or one parent may be "in charge" of the medical care of the child and another caregiver might happen to be the one present at the time of pharmacists' information gathering. Additionally, information related to symptoms of illness will not be provided first-hand, but rely on observations made by the caregiver. This introduces a source of potential inaccuracy or missing information that is not as commonly encountered when patients provide their own history.

\section{Medical History}

While medical histories of children tend to be shorter than that of adults, this is not always the case and many pediatric patients may have long medical histories before they reach school age. Gathering this information is not different than gathering it for adult patients using a combination of patient (caregiver) history corroborated by medical records.

An important difference to note is that in infants (especially those in the first 3 months of life), maternal pregnancy and delivery history is relevant and should be gathered wherever possible as well. Maternal conditions during pregnancy and the circumstances of delivery may be very relevant to an infant's medical care. For instance, a mother using methadone for a substance abuse condition may result in her infant developing signs and symptoms of withdrawal several days after discharge home. Likewise, whether or not a mother received intrapartum prophylactic antibiotics is directly related to the infant's risk of Group B Streptococcus infection in the newborn period. Very few medications are contraindicated in breastfeeding, but knowing if an infant is receiving even small amounts of medications via breastmilk may be relevant if concerns arise regarding a potential drug interactions or adverse effect.

\section{Medication History}

As with medical history, medication histories are often shorter in duration and length in children as compared to adults. Again, there are exceptions to this in children with complex medical needs. All relevant details collected for adult medical histories should be collected for pediatric patients, with some additional factors to consider.
Many pediatric medications do not come from the manufacturer in appropriate formulations for administration to children, and thus asking about the formulation is an important step in pediatric medication history. Extemporaneously compounded liquids are especially risky for creating confusion, as often caregivers know the volume they provide to the child but not the concentrations. If there are multiple concentrations available due to variability in the "recipe" followed by the pharmacy during compounding, this can lead to dose errors and subsequent sequelae (see Box 28.1 for an example). If there are any questions regarding the strength of a formulation or volume given, call the pharmacy that provided the previous fill and clarify what was provided. Medications in tablet form (except many sustained or controlled release formulations) may be crushed or dissolved for ease of administration and the appropriateness of this practice should be assessed by the pharmacist depending on the size of the tablet, ease of splitting, and the possibility of alternate dosing intervals (e.g., a daily dose of ASA $20 \mathrm{mg}$ can be delivered as a half tablet [ $40 \mathrm{mg}$ ] every other day instead of a quarter tablet [20 mg] every day). Some medications may be given in a "dissolve-adose" manner, whereby a tablet is crushed and suspended in a small amount of liquid, then the dose is measured from the resulting suspension. Certainly, accurate dosing in this situation relies on appropriate suspension of the tablet, and this should be considered when doing an assessment of the patient's dose/response.

\section{Box 28.1 Example of an Error Related to} Formulation

There is no commercially available clonidine oral liquid on the market, so it is commonly compounded by pharmacies for use in infants and children who cannot swallow tablets or who require very small doses.

A $10-\mathrm{kg}$ child named Colin is discharged from a hospital with a prescription for clonidine 50 micrograms PO q6h. His parents fill the prescription at the outpatient 
pharmacy within the hospital on their way home. The outpatient pharmacy provides them with $500 \mathrm{~mL}$ of 10 micrograms $/ \mathrm{mL}$ compounded clonidine suspension with instructions to take $5 \mathrm{~mL}$ four times a day.

Colin's parents go to their neighborhood pharmacy for the next refill. That pharmacy only has a recipe for clonidine 100 micrograms $/ \mathrm{mL}$ oral liquid and so fills the prescription with that suspension (with instructions to give $0.5 \mathrm{~mL}$ four times a day). At home Colin's parents are used to giving $5 \mathrm{~mL}$ four times daily and so continue to do so. In a couple of days, Colin is acting lethargic and weak. His parents take him to the nearest emergency department and while they are reviewing the medications with the team, the pharmacist there discovers the error - a 10 times overdose of clonidine.

Even with commercially available appropriate formulations, administration of pediatric medications can be especially challenging. Literature shows that measurement errors are common in caregivers of children and so observing the caregivers measure (and administer if appropriate) the medications may provide insight into dosing appropriateness [12]. Considerations regarding the measurement device should also be made. Household teaspoons are not appropriate for measuring medications, and even some medication syringes do not have appropriate markings for accurate measurement of small doses. Ensuring an appropriate measuring device is an important part of a pharmacist's assessment of dosing accuracy (Fig. 28.1).

Likewise, how a caregiver gives the medication to the child may be relevant. Medications mixed in a small amount of food/milk immediately prior to administration is appropriate, but if it is mixed in a large amount that the child does not consume all of, the dose taken will not be correct. Medications given on an "empty stomach" or to be avoided with dairy products are not likely to be given according to these restrictions in new-

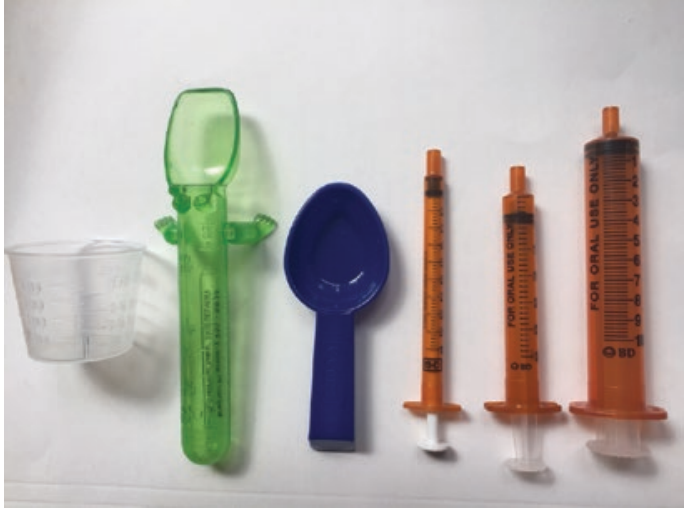

Fig. 28.1 Examples of inappropriate (three on left) and appropriate measuring devices

born infants who typically feed every 3-4 hours. In these cases, the medication may be given with feeds (formula or breastmilk) for ease of administration, but a slightly higher dose may need to be used empirically, or the dose may be titrated up based on monitoring parameters (e.g., levothyroxine based on TSH). If this occurs, the administration conditions should be kept consistent for the individual patient, even if "manufacturer recommendations" suggest otherwise. Parents and caregivers may ask if it is appropriate to mix all of a child's medications together in one syringe/cup prior to administration. This practice should ideally be discouraged as it may contribute to inaccurate measurement, potential incompatibilities, and will present challenges with re-dosing or estimating the portion of dosages consumed if only part of the "mixture" is taken/ spit-up.

Other things to consider in the medication history of infants and children include medication storage, timing, and palatability. Depending on the frequency of administration of a medication and the child's schedule (school, activities), mediation may not always be stored in an ideal manner. Medications may have to go to the soccer field or to the day home, for instance, and storage conditions may be affected during transitions. The timing of medications may be impacted by adults' schedules or bedtimes. For instance, if a medication is meant to be given every 6 hours around the clock, it may have to be given four 
times daily (QID) instead to accommodate bedtimes. Lastly, an assessment of the palatability of the medication formulation and the caregiver's report of how often the child takes/receives their full dose should be completed. These types of issues will be further explored in the section on adherence assessment.

\section{Indication Assessment}

Like in the adult setting, "Is this therapy indicated?" is an important question to be assessed by the pharmacist. Due to the relative lack of studies in pediatric patients, often medications that do not have an official indication in pediatrics are used (pediatric use is not included in the product monograph). Because of the lack of appropriate information in the product labeling, alternative data sources need to be accessed to assess the use of the medication in an infant or child. Pediatric medication information sources should be available and reviewed to aid in this part of the assessment, but primary literature may also have to be consulted more often than in adults.

Assessing whether or not an agent is "firstline" or "ideal" for a child includes special considerations that may not be as necessary in adult patients. An agent may be selected not because it has the best data to support it, but because it is the ONLY agent with pediatric dosing information, or because it is the only one with a formulation appropriate for the age group (or it has the best tasting formulation). A medication may be selected because it has a less frequent administration schedule, accommodating a child's school or activity schedule, or to limit the number of dosage times due to unpleasantness of administration (e.g., bad taste or painful injection). In this sense, assessment of whether or not a medication is the most appropriate choice for the patient is increasingly challenging.

Because of differences in pathophysiology or pharmacodynamics in pediatric patients as compared to adults, an "appropriate" or "ideal" medication choice in adults may be quite different in pediatrics. Likely pathogens in bacterial infec- tions differ between age groups, the causes of thrombosis or hypertension are very different in children as compared to adults, and systemic steroids can have very different safety profiles depending on the age of the child. For this reason, complete assessment of whether or not a medication is "indicated" for a child requires much more in depth look into references than for a typical adult patient. Pediatric or neonatal guidelines, reviews, studies, and other literature need to be consulted for this component of the assessment. One cannot rely on what is appropriate in adult patients to be appropriate in newborns, infants, or children.

\section{Dose Assessment}

As alluded to above, comprehensive dose assessment in pediatric patients requires several more steps than in adult patients. First, the pharmacist needs to determine how the medication dose is characterized: by gestational age (in newborns), post-natal age, by body weight, by body surface area, or some combination of the above.

Once that is determined, the pharmacist must gather the needed information to categorize the patient into the appropriate dosing range using a pediatric dosing reference. A common error is to use pediatric doses for neonates; therefore, the age of infants needs to be confirmed. In addition to selection of the appropriate dosing category, the pharmacist must also ensure that the appropriate dose for the indication in question is considered. Doses for medications can vary significantly for different indications. For example, the ASA dose for antiplatelet effects is 1-5 mg/kg/day, where anti-inflammatory doses range from 60 to $100 \mathrm{mg} / \mathrm{kg} / \mathrm{day}$.

The next step is another common source of error: calculations. Doses should never be estimated and calculations should never be done in the pharmacist's head. A calculator is an essential tool for pediatric pharmacists. Pediatric doses are typically listed in $\mathrm{mg} / \mathrm{kg} / \mathrm{DAY}$ divided $\mathrm{qXh}$, or can be listed as $\mathrm{mg} / \mathrm{kg} / \mathrm{DOSE}$ given $\mathrm{qXh}$. This is a common source of error and must be carefully checked by the pharmacist. While it is common 
to see pediatric doses that are higher than adult doses on a $\mathrm{mg} / \mathrm{kg}$ basis because of the pharmacokinetic differences noted above, it is important to note that adult maximum daily doses (total $\mathrm{mg}$ ) should typically still be observed in pediatric patients. Box 28.2 provides an example.

Many medications that children use are on a short-term basis only (e.g., antibiotics); however, with medications that are used on an ongoing basis, pharmacists need to ensure that doses are checked with each fill. Children, and especially infants, grow quickly and medications dosed on a $\mathrm{mg} / \mathrm{kg}$ basis may need adjustment for growth. Each fill is an opportunity for the pharmacist to assess the need to continue a medication, its apparent effectiveness and the presence of any adverse effects as part of the decision as to whether or not to increase the dose (or discontinue it altogether, if appropriate).

\section{Box 28.2 An Example of a Pediatric Dose Approaching an Adult Dose}

Rex is a 12-year-old boy being treated for a pneumonia using amoxicillin. He weighs $40 \mathrm{~kg}$.

His prescription states:

$90 \mathrm{mg} / \mathrm{kg} /$ day $=1350 \mathrm{mg}$ PO TID $\times 7$ days

While $90 \mathrm{mg} / \mathrm{kg}$ is much higher than most adults would receive, this is an appropriate dose for pneumonia in children. However, the adult maximum daily dose of amoxicillin for pneumonia is $3000 \mathrm{mg}$, so Rex's dose should be adjusted to $1000 \mathrm{mg}$ PO TID even though this will only be $67 \mathrm{mg} / \mathrm{kg} /$ day.

Lastly, the pharmacist needs to identify an appropriate formulation; the one that allows the dose to be measured accurately, is (reasonably) palatable, and has suitable stability. As mentioned above, this may be a significant challenge on its own. As an additional challenge, newborns $<44$ weeks CGA should ideally not use medica- tions containing preservatives (e.g., benzyl alcohol, propylene glycol) and children should ideally not use medications containing alcohol. This is due to adverse effects reported with these additives (gasping syndrome, metabolic acidosis, hypoglycemia) [13, 14]. However, if an alternative, preservative-free and/or alcohol-free product is not available, the benefit of the medication should outweigh the risks from a small dose of alcohol or preservative.

\section{Monitoring: Efficacy and Safety}

\section{Symptom Assessment}

In pediatrics, often patients are non-verbal or are not at a developmental stage where they can describe their symptoms and so a caregiver's external assessment of the patients' symptoms must be relied upon. There is a greater focus on observation of signs and symptoms when determining a patients need or response to medications. While these observations have some degree of objectivity, many assessments done in this way may include some subjectivity. For this reason, other objective measures may be relied upon more frequently in younger children than in older children or adults. For instance, the objective presence of a fever and results of key lab values (e.g. normalization of white blood cell count) can supplement a parent's subjective report of a child feeling better and acting more "like himself" in an assessment of an infection's response to antibiotics. Pain scoring tools that include a measurement of heart rate, blood pressure, as well as an observation of the infants' behavior can add an objective component to a parent's assessment of their child's pain. There are a variety of pediatricspecific assessment tools for a variety of medical conditions and pharmacists should seek those out when needed. Table 28.2 includes some examples of condition-specific assessment tools for infants and children. It should be noted that dismissing a parent's assessment of their child due to its subjectivity is not advised. Caregivers know typical behavior in their children and slight changes in behavior (e.g., poor feeding, decreased energy, altered sleep) can be important signs of 
illness or adverse medication effects in children. Having said that, if subjective observations contradict objective measures, one should proceed with caution. When assessing a child's illness, there are some red flags that should illicit immediate referral to medical care. Table 28.3 depicts a list of the red flag symptoms that prompts referral in pediatric patients.

Table 28.2 Examples of pediatric-specific assessment tools [15-21]

\begin{tabular}{|l|l|}
\hline Condition & Assessment tool \\
\hline Pain & $\begin{array}{l}\text { Premature Infant Pain Profile (PIPP) } \\
\text { Face, Legs, Activity, Cry and Consolability } \\
\text { scale (FLACC) } \\
\text { Faces Pain Scale }\end{array}$ \\
\hline Sedation & $\begin{array}{l}\text { State Behavior Scale (SBS) } \\
\text { COMFORT scale }\end{array}$ \\
\hline Nausea & $\begin{array}{l}\text { Pediatric Nausea Assessment Tool (PeNAT) } \\
\text { Asthma }\end{array}$ \\
& $\begin{array}{l}\text { Childhood Asthma Control Test (C-ACT) } \\
\text { (asthma control) } \\
\text { Pediatric Respiratory Assessment Measure } \\
\text { (PRAM) (asthma exacerbation) }\end{array}$ \\
\hline
\end{tabular}

Table 28.3 Red flag symptoms in pediatrics that prompts immediate referral to health care practitioner [22, 23]

\begin{tabular}{|c|c|}
\hline System & Symptom \\
\hline $\begin{array}{l}\text { General } \\
\text { appearance }\end{array}$ & Increasing lethargy/confusion \\
\hline Vital signs & $\begin{array}{l}\text { Rash with fever } \\
\text { Fever in infant }<3 \text { months old } \\
\text { Very fast or very slow heart rate } \\
\text { (see Table } 28.4 \text { for age-based } \\
\text { normals) } \\
\text { Elevated respiratory rate at rest (see } \\
\text { Table } 28.4 \text { for age-based normals) }\end{array}$ \\
\hline $\begin{array}{l}\text { Central nervous } \\
\text { system }\end{array}$ & $\begin{array}{l}\text { Change in/loss of consciousness } \\
\text { Lack of response to pain } \\
\text { Decreased tone/floppiness } \\
\text { Seizure-like activity }\end{array}$ \\
\hline Cardiovascular & $\begin{array}{l}\text { Very fast or very slow heart rate } \\
\text { (see Table } 28.4 \text { for age-based } \\
\text { normal values) }\end{array}$ \\
\hline Respiratory & $\begin{array}{l}\text { Very fast respiratory rate (see } \\
\text { Table } 28.4 \text { for age-based normal } \\
\text { values) } \\
\text { Labored or noisy breathing } \\
\text { Irregular or absent respiration }\end{array}$ \\
\hline Dermatological & $\begin{array}{l}\text { Skin color changes - dusky/blue } \\
\text { Very dry lips or mouth }\end{array}$ \\
\hline Genitourinary & $\begin{array}{l}\text { Severely reduced/lack of urine } \\
\text { output }\end{array}$ \\
\hline
\end{tabular}

\section{Physical Assessment}

Physical assessment in pediatrics can be limited by both the pharmacists' knowledge of the nuances of pediatric physical exam and by the patient's tolerability of the exam itself. It is beyond the scope of this chapter to describe the differences in physical exam between children and adults, but vital sign assessment can be a simple addition to a pharmacists' assessment in many cases, and the major differences between children and adults are summarized in Table 28.4.

\section{Lab Values}

As in adults, lab values are an important part of assessing both the efficacy and toxicities of medications in children. Table 28.5 outlines some of the most commonly used laboratory values and how they differ between children and adults.

Monitoring renal function is especially important for pharmacists, both for assessing the need for dose adjustment in renal dysfunction, but also for monitoring for nephrotoxicity of medications. Because normal ranges of serum creatinine in children are relatively wide, serum creatinine values can double, reflecting potential acute kidney injury, but remain in the "normal" range. It is important therefore for pharmacists to follow trends in serum creatinine rather than just absolute values. In cases where the pharmacist needs to estimate renal function, the formula used in children differs from that used in adults. The most accurate and commonly used formula is called the "Bedside Schwartz" formula. Equation 28.1 outlines this important formula. Estimation of GFR in infants and especially in newborns is challenging as renal function continues to develop rapidly after birth, with most infants reaching full renal function around 6 months of age. Again, following trends in serum creatinine (expecting a downward trend in the first 1-2 weeks of life) is the most effective method of assessing renal function. Other factors such as urine output and hydration should also be considered in the overall assessment of renal function. Renal dysfunction in children is fortunately uncommon, and all children with renal dysfunction should be followed by a pediatric nephrology team.

"Bedside Schwarz" formula for estimating glomerular filtration rate (GFR) in children $>1$ year of age [30]: 
Table 28.4 Typical normal vital sign ranges, comments on physical exam in children [24-26]

\begin{tabular}{|c|c|c|c|}
\hline Age group & $\begin{array}{l}\text { Normal } \\
\text { respiratory rate } \\
\text { (breaths per } \\
\text { minute) }\end{array}$ & $\begin{array}{l}\text { Definition of } \\
\text { tachypnea (breaths } \\
\text { per minute) }\end{array}$ & Comments on pediatric respiratory exam \\
\hline Newborn & $34-50$ & $>60$ & \multirow{4}{*}{$\begin{array}{l}\text { Respiratory rate is best measured when baby is } \\
\text { settled or sleeping, not crying. } \\
\text { Increased work of breathing can be indicated by } \\
\text { nasal flaring, subcostal and intracostal retraction, } \\
\text { head bob, or tracheal tug. } \\
\text { Infants and children have narrower airways and a } \\
\text { small degree of inflammation can reduce the diameter } \\
\text { significantly (e.g., croup). } \\
\text { Infants less than a year of age are obligate nasal } \\
\text { breathers and nasal congestion can be a significant } \\
\text { source of respiratory distress, in addition to being a } \\
\text { cause of poor feeding. } \\
\text { Noisy breathing including wheeze, stridor, or } \\
\text { grunting are signs of respiratory distress and should } \\
\text { be referred }\end{array}$} \\
\hline Infant & $25-40$ & $>50$ & \\
\hline $\begin{array}{l}\text { Child } \\
1-5 \text { years }\end{array}$ & $20-30$ & $>40$ & \\
\hline $\begin{array}{l}\text { Child }>5 \text { years } \\
\text { and } \\
\text { adolescents }\end{array}$ & $15-25$ & $>30$ & \\
\hline Age group & $\begin{array}{l}\text { Normal heart } \\
\text { rate when awake }\end{array}$ & $\begin{array}{l}\text { Normal heart rate } \\
\text { when sleeping }\end{array}$ & Comments on cardiac exam in pediatrics \\
\hline Newborn & $100-205$ & $90-160$ & \multirow{6}{*}{$\begin{array}{l}\text { "Exercise" in infants is best represented by feeding, } \\
\text { thus poor feeding/sweating while feeding may be a } \\
\text { sign of cardiac compromise. } \\
\text { Congenital heart defects are a common cause of } \\
\text { cardiac compromise in infants - echocardiography is } \\
\text { required to assess heart structure. } \\
\text { It is important to assess a child's heart rate at rest and } \\
\text { not when they are crying/upset }\end{array}$} \\
\hline Infant & $100-190$ & $90-160$ & \\
\hline $\begin{array}{l}\text { Toddler } \\
(1-2 \mathrm{y})\end{array}$ & $100-140$ & $80-120$ & \\
\hline $\begin{array}{l}\text { Preschooler } \\
(3-5 \mathrm{y})\end{array}$ & $80-120$ & $65-100$ & \\
\hline $\begin{array}{l}\text { School-age } \\
(6-11 \mathrm{y})\end{array}$ & $75-120$ & $60-90$ & \\
\hline Adolescent & $60-100$ & $50-90$ & \\
\hline Age group & $\begin{array}{l}\text { Normal systolic/ } \\
\text { diastolic blood } \\
\text { pressure (mmHg) }\end{array}$ & $\begin{array}{l}\text { Definition of } \\
\text { hypotension - systolic } \\
(\mathrm{mmHg})\end{array}$ & $\begin{array}{l}\text { Comments on pediatric blood pressure } \\
\text { measurement in pediatrics }\end{array}$ \\
\hline Neonates & $70-85 / 35-55$ & $<60$ & \multirow{5}{*}{$\begin{array}{l}\text { BP measurement requires pediatric-specific, } \\
\text { appropriately sized-cuffs. } \\
\text { Definitions of hyper- and hypo-tension require } \\
\text { knowledge of the child's age/gender based } \\
\text { percentile of height and use of specific blood } \\
\text { pressure tables. } \\
\text { A quick way to estimate normal systolic blood } \\
\text { pressure in a child: median systolic blood } \\
\text { pressure }=2(\text { age })+90 \mathrm{mmHg} \\
\text { The most common cause of hypertension in children } \\
\text { are renal pathologies, which differs significantly from } \\
\text { adults }\end{array}$} \\
\hline Infant & $70-100 / 40-55$ & $<70$ & \\
\hline Child up to $5 \mathrm{y}$ & $90-110 / 40-70$ & $\begin{array}{l}<70+\text { (age in years } x \\
2 \text { ) }\end{array}$ & \\
\hline $\begin{array}{l}\text { Child }>5 \text { y to } \\
11 \mathrm{y}\end{array}$ & $100-120 / 60-80$ & $\begin{array}{l}<70+\text { (age in years } x \\
\text { 2) }\end{array}$ & \\
\hline Adolescent & $110-130 / 65-85$ & $<90$ & \\
\hline
\end{tabular}

$$
\begin{aligned}
\operatorname{GFR} & \left(\mathrm{ml} / \mathrm{min} / 1.73 \mathrm{~m}^{2}\right) \\
= & \frac{36.2 \times \operatorname{Height}(\mathrm{cm})}{\text { Serum Creatinine }(\mu \mathrm{mol} / \mathrm{L})}
\end{aligned}
$$

Because infectious diseases are commonplace in children, interpretation of bacterial cultures is worth mentioning. Sputum cultures are challenging as contamination with saliva is common. It is therefore necessary to note the presence of endothelial cells and/or nasopharyngeal flora in these cultures as they may indicate a lack of appropriate specimen. Urinary samples, likewise, can be difficult to obtain appropriately without catheterization and thus have a higher likelihood of contamination by skin flora. Lastly, there is a higher rate of false- 
Table 28.5 Common lab values used for monitoring medications and how they differ in children [27-29]

\begin{tabular}{|c|c|c|}
\hline Lab value & Normal values & Comments \\
\hline Hemoglobin & $\begin{array}{l}\text { Birth } 150-200 \mathrm{~g} / \mathrm{L} \\
\text { Nadir }(\text { in term infants })=90-110 \mathrm{~g} / \mathrm{L}, \text { occurs } \\
\sim 6-8 \text { weeks of age } \\
\text { Nadir (in preterm infants) }=60-80 \mathrm{~g} / \mathrm{L}, \\
\text { occurs } \sim 3-7 \text { weeks of age } \\
\text { Normalizes (adult values) } \sim 6 \text { months of age }\end{array}$ & $\begin{array}{l}\text { It is normal for infants to have a drop in } \mathrm{Hgb} \\
\text { following birth, due to a switch from fetal to adult } \\
\text { hemoglobin }\end{array}$ \\
\hline $\begin{array}{l}\text { White blood } \\
\text { cells }\end{array}$ & $\begin{array}{l}\text { Neonate } 9-30 \text { cells } / \mathrm{mm}^{3} \\
\text { Infant } 6-18 \text { cells } / \mathrm{mm}^{3} \\
\text { Child } 5-15 \text { cells } / \mathrm{mm}^{3} \\
\text { Adolescence } \sim \text { adult values }\end{array}$ & $\begin{array}{l}\text { Newborns may have a decrease in white blood cells in } \\
\text { response to infection as cells are used up and replaced } \\
\text { at a slower rate }\end{array}$ \\
\hline Platelets & Same as adults & $\begin{array}{l}\text { Newborns may have slightly lower platelets counts, } \\
\text { with a lower limit of } 150 \times 10^{9} / \mathrm{L}\end{array}$ \\
\hline Electrolytes & Same as adults & $\begin{array}{l}\text { Newborns may have slightly lower sodium (some } \\
\text { sodium wasting due to renal immaturity) and higher } \\
\text { K (normal state of potassium retention) values than } \\
\text { infants and children } \\
\text { Serum phosphate also tends to be higher in infants } \\
\text { and children due to high needs during bone growth } \\
\text { and high energy needs }\end{array}$ \\
\hline Creatinine & $\begin{array}{l}\text { Newborns } 27-88 \mu \mathrm{mol} / \mathrm{L} \\
\text { Infants } 18-35 \mu \mathrm{mol} / \mathrm{L} \\
\text { Children } 27-62 \mu \mathrm{mol} / \mathrm{L} \\
\text { Adolescents } 44-88 \mu \mathrm{mol} / \mathrm{L}\end{array}$ & $\begin{array}{l}\text { Note that creatinine in the first few days of life often } \\
\text { reflects maternal renal function, and a downward } \\
\text { trend is expected in the first } 2 \text { weeks of life }\end{array}$ \\
\hline
\end{tabular}

negative blood cultures. Blood cultures in children are typically limited to two bottles (adults typically use four bottles), and use smaller volumes of blood, resulting in a higher risk of false-negative results. The reduced number of bottles also makes distinguishing between pathogenic growth and contamination more difficult. In adults, growth of skin flora in one out of four blood culture bottles is typically associated with contamination; however in children growth of the same pathogen in one out of two bottles is less convincing as contamination. For these reasons, it is not uncommon to empirically treat a child for an infection despite negative cultures, purely based on signs and symptoms of infection. This represents a particular challenge for pharmacists attempting to tailor antibiotic therapy to infectious pathogens. Antibiotic therapy may have to be assessed based on "typical" pathogens rather than actual.

When considering "typical" pathogens, these vary by age and so pharmacists need to consider this when assessing the appropriateness of antibiotic therapy. Another major factor in the "likely" bacteria pathogens is immunization status, and pharmacists should be familiar with vaccination history in patients presenting with infectious diseases. For instance, unimmunized children are at much higher risk of infection with Hemophilus influenza type B (HiB), which can be a significant pathogen in both meningitis and pneumonia. Table 28.6 outlines common pathogens in common infections throughout infancy and childhood, assuming vaccination in accordance with local immunization programs.

\section{Adherence Assessment}

An assessment of adherence in children should include not only overt nonadherence (e.g., the child dislikes the taste and spits it out, or the parent forgets to give it on the weekends) but also "covert" nonadherence (e.g., parents make measurement errors, or product is used beyond its stability date). Asking to see the caregiver show the dose given as measured, and an examination of the medication bottles can assist with this. Questions regarding the appropriate storage of 
Table 28.6 Common pathogens in common childhood infections [31-34]

\begin{tabular}{|c|c|c|}
\hline Infectious disease & Age group & Common pathogens \\
\hline \multirow[t]{4}{*}{ Meningitis } & Newborns & $\begin{array}{l}\text { Group B Streptococcus } \\
\text { E.coli } \\
\text { Other bacteria, including Listeria monocytogenes }\end{array}$ \\
\hline & Infants $1-2$ months & $\begin{array}{l}\text { Group B Streptococcus } \\
\text { Gram negative bacteria } \\
\text { Streptococcus pneumoniae } \\
\text { Neisseria meningitides }\end{array}$ \\
\hline & 3 months to 9 years & $\begin{array}{l}\text { Streptococcus pneumoniae } \\
\text { Neisseria meningitides }\end{array}$ \\
\hline & 10 years and up & $\begin{array}{l}\text { Neisseria meningitides } \\
\text { Streptococcus pneumoniae }\end{array}$ \\
\hline Acute otitis media & All ages & $\begin{array}{l}\text { Viruses (e.g., respiratory syncytial virus [RSV], } \\
\text { parainfluenza, influenza, adenovirus, coronavirus) } \\
\text { Streptococcus pneumoniae } \\
\text { Non-typeable Hemophilus influenza } \\
\text { Moraxella catarrhalis } \\
\text { Streptococcus pyogenes }\end{array}$ \\
\hline \multirow[t]{4}{*}{ Pneumonia } & Newborns & $\begin{array}{l}\text { Group B Streptococcus } \\
\text { Gram-negative enteric bacteria } \\
\text { Ureaplasma urealyticum }\end{array}$ \\
\hline & Infants $<3$ months & $\begin{array}{l}\text { Chlamydia trachomatis } \\
\text { RSV } \\
\text { Parainfluenza } \\
\text { Streptococcus pneumoniae } \\
\text { Bordetella pertussis }\end{array}$ \\
\hline & Children $\leq 5$ years & $\begin{array}{l}\text { Respiratory viruses (e.g., RSV, parainfluenza, human } \\
\text { metapneumovirus) } \\
\text { Streptococcus pneumoniae } \\
\text { Mycoplasma pneumoniae } \\
\text { (Note that Staph aureus can be a common cause of post- } \\
\text { influenza pneumonia) }\end{array}$ \\
\hline & Children $>5$ years and up & $\begin{array}{l}\text { Mycoplasma pneumoniae } \\
\text { Chlamydia pneumoniae } \\
\text { Streptococcus pneumoniae }\end{array}$ \\
\hline Urinary tract infections & All ages & $\begin{array}{l}\text { Escherichia coli } \\
\text { Klebsiella } \\
\text { Proteus } \\
\text { Enterococcus } \\
\text { Pseudomonas }\end{array}$ \\
\hline
\end{tabular}

medication are also important (e.g., using coolers for refrigerated medications on long trips).

\section{Measurability}

The variability of dosages required for children often make the use of solid dosage forms impractical. If the tablet is appropriate to split, and if a child's dose can be rounded to accommodate a half (or even quarter) tablet, this may be the most practical approach. However, in younger children and for smaller doses, the use of oral liquids may be the only solution. Oral liquids should be mea- sured in appropriately sized devices. Often, especially in infants, doses may be so small that accurate measurement becomes challenging. Doses less than $1 \mathrm{~mL}$ are ideally measured in $1 \mathrm{~mL}$ (or even $0.5 \mathrm{~mL}$ ) oral syringes in order to maximize accuracy. Typically, manufacturer guidance dictates that doses $<10 \%$ of the syringe size cannot be accurately measured (e.g., no less than $0.1 \mathrm{~mL}$ in a $1 \mathrm{~mL}$ syringe or $0.05 \mathrm{~mL}$ in a $0.5 \mathrm{~mL}$ syringe).

Occasionally, unique solutions to measurability issues need to be explored. Very small doses of 
some injectable products (e.g., enoxaparin doses $<10 \mathrm{mg}$ ) may be most easily measured using an insulin syringe (e.g., 1 unit $=0.01 \mathrm{~mL}=1 \mathrm{mg}$ enoxaparin). Very small doses of oral medications only available in capsules may require (very careful) preparation of powder papers which involves weighing of powders from capsules and packaging in specially folded papers. Whatever the situation, pharmacists must ensure that parents and caregivers using medications in children have an accurate method of measurement available as well as a practical approach to giving the medication.

\section{Palatability}

If a medication must be delivered to the child as an unpalatable oral liquid there are some approaches to helping mask the taste of the medication. In infants, most medications can be mixed with a small amount of formula or breastmilk to improve palatability. It is important to instruct parents or caregivers not to mix medications in a full volume of feed (i.e., a full bottle) as the complete dose may not be delivered if the full amount of feed is not taken. Older children may find eating frozen treats prior to taking the medication may numb the tongue enough and reduce the bad taste. Similarly, allowing the child to choose a food or drink to wash the medication taste away may be helpful. Concentrated, sugary beverages or foods (honey, chocolate syrup) or other strongly flavored foods (cheeses) may help mask or remove the taste from the child's mouth.

\section{Medication Administration}

Administering oral medications to children can be a significant challenge in itself. After measurement with an appropriate device, oral liquids can be given to infants mixed with a small amount of milk/formula through a bottle nipple, or for older children they can be mixed in a small amount of palatable food or liquid before administration. Alternatively, oral liquids can simply be expelled into the cheek (where there are no tastebuds) followed with a drink of palatable liquid. Iron liquid can stain teeth, and so rinsing the mouth is important (can also use a straw if the mediation has been diluted in a liquid). Note that these precau- tions are unnecessary in infants without teeth, and most important in those with their permanent teeth.

The ability to swallow oral solid dosage forms makes oral medication administration easier, and this can usually occur around age 5 or 6 years. If children struggle with pill swallowing, they can practice with candies with increasing sizes (e.g., start with sprinkles, slowly increasing the size of the candies up to the target tablet size. Usually small jelly beans are sufficiently sized for most medications). Children can place the medication/candy on the back of their tongue, tilt their head back, and have a large drink of liquid to facilitate this. In rare cases, infants and small children can swallow small oral dosage forms with appropriate instruction from qualified professionals. An example is levothyroxine, where crushed tablets and suspensions may not provide the necessary accuracy and part-tablets are the preferred dosage form.

Medications to be administered via feeding tubes (e.g., nasogastric tubes, gastrojejunal tubes) can be administered without palatability concerns; however the intestinal location of the medication administration should be considered in the context of the intestinal administration site (e.g., ensure the medication can be absorbed if administered into the jejunum), and the tubes should be flushed with water afterward to ensure complete delivery of the dose.

\section{Adolescents}

As a final comment on adherence assessment, it is important to consider adolescents specifically. Increasing independence with medication use and administration is often given to adolescents as they move toward adulthood, which requires a change in the pharmacist's approach. Where previously assessment was conducted primarily with the caregivers on behalf of the child, the pharmacist should begin to include the adolescents in these conversations in an attempt to build their health literacy and knowledge of their conditions/medications. Also of note, adolescents often become more self-conscious of their medical conditions and associated medication use, and strategies to increase the discreteness of 
Table 28.7 Pediatric assessment steps, common errors, and tips to avoid errors

\begin{tabular}{|c|c|c|}
\hline Step in assessment & Common errors & Pediatric considerations \\
\hline 1. Information gathering & $\begin{array}{l}\text { Caregivers confusing } \mathrm{mg} \text { with } \mathrm{mL} \text { when } \\
\text { stating dose } \\
\text { Unknown or incorrect concentration } \\
\text { dispensed }\end{array}$ & $\begin{array}{l}\text { Try to take history from most } \\
\text { appropriate caregiver. } \\
\text { Include maternal history if }<3 \text { months of } \\
\text { age } \\
\text { Include formulation, strength, and } \\
\text { administration details in medication } \\
\text { history }\end{array}$ \\
\hline 2. Indication assessment & Unfamiliarity with pediatric indications & $\begin{array}{l}\text { Be sure to use pediatric references } \\
\text { Consider "other" reasons for selection of } \\
\text { agent-administration schedules, } \\
\text { palatability, and availability of pediatric } \\
\text { data }\end{array}$ \\
\hline 3. Dosage assessment & $\begin{array}{l}\text { Mathematical errors } \\
\text { Using dose for wrong age group } \\
\mathrm{mg} / \mathrm{kg} / \text { day vs } \mathrm{mg} / \mathrm{kg} / \mathrm{dose} \\
\text { Exceeding adult daily maximum dosage } \\
\text { Patients outgrowing doses of chronic } \\
\text { medications }\end{array}$ & $\begin{array}{l}\text { Use neonatal doses for neonates, age } \\
\text { appropriate pediatric doses for infants } \\
\text { and children } \\
\text { Check dose for specific indications } \\
\text { Double check math } \\
\text { Consider growth with medications used } \\
\text { chronically } \\
\text { Keep adult maximum daily doses in } \\
\text { mind }\end{array}$ \\
\hline $\begin{array}{l}\text { 4. Efficacy and safety } \\
\text { assessment }\end{array}$ & $\begin{array}{l}\text { Unfamiliarity with pediatric "normal" } \\
\text { values for physical exam or laboratory } \\
\text { parameters }\end{array}$ & $\begin{array}{l}\text { Try to include objective and subjective } \\
\text { measures } \\
\text { Physical exam, laboratory values, } \\
\text { assessment of renal function, and typical } \\
\text { pathogens may differ from adults }\end{array}$ \\
\hline 5. Adherence assessment & $\begin{array}{l}\text { "Covert" non-adherence (parents } \\
\text { inappropriately measuring medications or } \\
\text { using compounded medications beyond } \\
\text { expiry date) }\end{array}$ & $\begin{array}{l}\text { Ensure caregivers have a practical } \\
\text { approach to measurement and } \\
\text { administration of the required doses } \\
\text { Assess for palatability issues } \\
\text { Observe measurement and/or } \\
\text { administration of medications by } \\
\text { caregivers } \\
\text { Help transition adolescents to adulthood } \\
\text { and independent medication use }\end{array}$ \\
\hline
\end{tabular}

their medication use may be appreciated and improve adherence. For example, selection of a dry powder inhaler instead of a metered-dose inhaler with spacer device, or choosing a once or twice-a-day administered agent instead of one that has to be used at school. Considerations such as these should come into a pharmacist's assessment as their pediatric patients move toward adulthood.

Assessing medication use in children has many similarities to that in adults, and should be approached in a similarly systematic way, bearing slight nuances in mind. Table 28.7 summarizes the approach to pediatric assessment, highlights common sources of errors, and provides some tips for minimizing these errors.

\section{Clinical Pearls}

- Assessment of dose requires additional steps in children as compared to adults - categorization by age/weight, calculation of appropriate dose, and determination of accurate measurement processes are a few major steps that need to be included.

- Infants and children have variable pharmacokinetic and pharmacodynamic parameters, and thus dosages vary widely. The use of pediatric/neonatal references is essential for appropriate dosing and indication assessment by pharmacists.

- Finding appropriate formulations for children is a challenge for pharmacists. Careful assessment 
of doses/concentrations, measurability, and method of administration need to be included in the overall medication assessment for infants and children.

- Interpretation of diagnostic tests and vital signs varies in children and a basic understanding of these differences is important for pharmacists assessing children medication therapy.

Acknowledgements The author wishes to express gratitude to Jenny Wichart and Kristen Blundell for their thoughtful reviews and comments.

\section{References}

1. Canadian Institute for Health Information, Discharge Abstract Database, 2016-17 [Internet]. Ottawa (ON): The Institute; 2017 [cited 2018 May 30]. 18 p. Available from: https://www.cihi.ca/sites/default/ files/document/dad-data-quality_16-17_en.pdf.pdf.

2. Council of Canadian Academies, 2014. Improving Medicines for Children in Canada. Ottawa (ON): The Expert Panel on Therapeutic Products for Infants, Children, and Youth, Council of Canadian Academies. [Internet] Ottawa (ON): Council of Canadian Academies, 2014. [cited April 18, 2018].292 p. Available from: http://www.scienceadvice.ca/uploads/eng/assessments $\% 20$ and $\% 20$ publications $\% 20$ and $\% 20$ news $\% 20$ releases/therapeutics/ therapeutics_fullreporten.pdf.

3. Abi Khaled L, Ahmad F, Brogan T, Fearnley J, Graham J, MacLeod S, et al. Prescription medicine use by one million Canadian children. Paediatr Child Health. 2003;8(Suppl A):6A-56A.

4. Zhang T, Smith MA, Camp PG, Shajari S, MacLeod SM, Carleton BC. Prescription drug dispensing profiles for one million children: a population-based analysis. Eur J Clin Pharmacol. 2013;69:581-8.

5. Vernacchio L, Kelly JP, Kaufman DW, Mitchell AA. Medication use among children $<12$ years of age in the United States: results from the Slone Survey. Pediatrics. 2009;124:446-54.

6. Buck ML. Pediatric pharmacotherapy. In: Alldredge BK, Corelli RL, Ernst ME, et al., editors. KodaKimble and Young's applied therapeutics. 10th ed. Philadelphia: Lippincott, Williams, \& Wilkins; 2013. p. 2265-76.

7. Crowley E, Williams R, Cousins D. Medication errors in children: a descriptive summary of medication error reports submitted to the United States Pharmacopeia. Curr Ther Res. 2001;26:627-40.

8. Zed PJ, Black KJL, Fitzpatrick EA, Ackroyd-Stolarz S, Murphy NG, Curran JA, et al. Medication- related emergency department visits in pediatrics: a prospective observational study. Pediatrics. 2015; 135:435-43.

9. Temple ME, Robinson RF, Miller JC, Hayes JR, Nahata MC. Frequency and preventability of adverse drug reactions in paediatric patients. Drug Saf. 2004;26:819-29.

10. Kearns GL, Abdel-Rahman SM, Alander SW, Blowey DL, Leeder JS, Kauffman RE. Developmental pharmacology - drug disposition, action, and therapy in infants and children. $\mathrm{N}$ Engl $\mathrm{J}$ Med. 2003;349:1157-67.

11. Bartelink IH, Rademaker CMA, Schobben AFAM, van den Anker JN. Guidelines on paediatric dosing on the basis of developmental physiology and pharmacokinetic considerations. Clin Pharmacokinet. 2006;45(11):1077-97.

12. Yin HS, Parker RM, Sanders LM, Dreyer BP, Mendelsohn AL, Bailey S, et al. Liquid medication errors and dosing tools: a randomized controlled experiment. Pediatrics. 2016;138(4):e20160357.

13. Whittaker A, Currie AE, Turner MA, Field DJ, Mulla $\mathrm{H}$, Pandya HC. Toxic additives in medication for preterm infants. Arch Dis Child Fetal Neonatal Ed. 2009;94:F236-40.

14. Nahata MC. Safety of "inert" additives or excipients in paediatric medicines. Arch Dis Child Fetal Neonatal Ed. 2009;94:F392-3.

15. Stevens B, Johnston C, Taddio A, Gibbins S, Yamada J. The premature infant pain profile: evaluation 13 years after development. Clin J Pain. 2010;26(9):813-30.

16. Merkel SI, Shayevitz JR, Voepel-Lewis T, Malviya S. The FLACC: a behavioral scale for scoring postoperative pain in young children. Pediatr Nurs. 1997;23:293-7.

17. Hicks C, von Baeyer C, Spafford P, van Korlaar I, Goodenough B. The Faces Pain Scale - Revised: toward a common metric in pediatric pain measurement. Pain. 2001;93:173-83.

18. Curley MAQ, Harris SK, Fraser KA, Johnson RA, Arnold JH. State Behavioral Scale (SBS) a sedation assessment instrument for infants and young children supported on mechanical ventilation. Pediatr Crit Care Med. 2006;7(2):107-14.

19. Ambuel B, Hamlett KW, Marx CM, Blumer JL. Assessing distress in pediatric intensive care environments: the COMFORT scale. J Pediatr Psychol. 1992;17(1):95-109.

20. Liu AH, Zeiger RS, Sorkness CA, Ostrom NK, Chipps BE, Rosa K, et al. The Childhood Asthma Control Test: retrospective determination and clinical validation of a cut point to identify children with very poorly controlled asthma. J Allergy Clin Immunol. 2010;126(2):267-73. 273.

21. Alnaji F, Zemek R, Barrowman N, Plint A. PRAM score as predictor of pediatric asthma hospitalization. Acad Emerg Med. 2014;21(8):872-8.

22. Wetzel GV. Red flags in common pediatric symptoms. MCN Am J Matern Child Nurs. 1999;24:37-44. 
23. Hospital for Sick Children [Internet]. Toronto: SickKids; c2014. Pediatric physical assessment [cited 2018 May 29]; [about 2 screens]. Available from: http://www.sickkids.ca/Nursing/Education-andlearning/Nursing-Student-Orientation/module-twoclinical-care/physicalassessment/index.html.

24. Le Saux N, Robinson JL, Canadian Paediatric Society, Infectious Diseases and Immunization Committee. Uncomplicated pneumonia in healthy Canadian children and youth: practice points for management. Paediatr Child Health. 2015;20:441-5.

25. Fleming S, Thompson M, Stevens R, Heneghan C, Pluddemann A, Maconochie I, et al. Normal ranges of heart rate and respiratory rate in children from birth to 18 years: a systematic review of observational studies. Lancet. 2011;377:1011-8.

26. National High Blood Pressure Education Program Working Group. Fourth Report on the Diagnosis, Evaluation, and Treatment of High Blood Pressure in Children and Adolescents. [Internet] National Institute of Health 2005. [cited April 18, 2018]
Available from: http://www.nhlbi.nih.gov/healthpro/guidelines/current/hypertension-pediatric-jnc-4/ blood-pressure-tables.

27. O'Brien RT, Pearson HA. Physiologic anemia of the newborn infant. J Pediatr. 1971;79:132-8.

28. Zhou H, Satlin LM. Renal potassium handling in healthy and sick newborn. Semin Perinatol. 2004;28:103-11.

29. Baum M, Quigley R. Ontogeny of renal sodium transport. Semin Perinatol. 2004;28:91-6.

30. Schwartz GJ, Work DF. Measurement and estimation of GFR in children and adolescents. J Am Soc Nephrol. 2009;4(11):1832-643.

31. Swanson D. Meningitis. Pediatr Rev. 2015;36(12):514-26.

32. Gould JM, Matz PS. Otitis media. Pediatr Rev. 2010;31(3):102-16.

33. Durbin WJ, Stille C. Pneumonia. Pediatr Rev. 2008;29(5):147-60.

34. Balighian E, Burke M. Urinary tract infections in children. Pediatr Rev. 2018;39(1):3-12. 